Literature

F2Lrfer review on crayfish 1991

ecology and

management methods 
MONTANA STATE LIBRARY

\$ 639.541 F2Lrfer 1991 c. 1 Thomas

Literature review on crayfish ecology an 


\section{LITERATURE REVIEW ON CRAYFISH ECOLOGY AND MANAGEMENT METHODS}

Prepared for: Montana Department of Fish, Wildlife, and Parks 1420 E. 6th Avenue

Helena, Montana 59620

By: Ginger Thomas, Fisheries consultant 521 Hartman street \#7 Missoula, Montana 59802

June 3, 1991

STATE DOCUMENTS COLLECTION

FEB 251992

MONTANA STATE LLBRARY

1515 ह. Gth AVE.

HELENA, MONTANA 59620

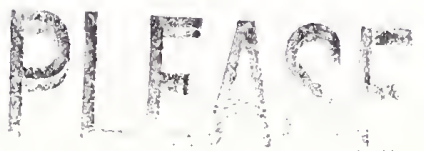


AUE 201999 


\section{INTRODUCTION}

The commercial harvest of crayfish began in Montana in 1988 . Prior to that time, crayfish were harvested on a small scale for personal use. Crayfish are a popular food in Europe, especially Sweden. The Swedes eat 4 to $6 \mathrm{million}$ pounds of crayfish per year (Larson 1989). A fungus has wiped out European crayfish populations and stimulated the market for American crayfish. The native western Montana species, Pacifasticus leniusculus resembles the European species and is especially favored in the European markets.

At the time that the commercial crayfishery started to develop in Montana, the Montana Department of Fish, Wildlife, and parks (MDFWP) had no regulations on the harvest of crayfish. There is concern among many sportsmen that a commercial crayfishery will have a negative impact on game fish. Montana declared the crayfish to be a non-game species in need of management so that regulations could be developed. In 1989, the Montana legislature directed that the MDFWP develop regulations governing the commercial harvest of crayfish, mysis shrimp, and other aquatic organisms. Current Montana crayfish regulations were developed under this statute. Interest in the commercial fishery continues to grow, as does the public controversy surrounding this fishery.

In addition, Montanans are also concerned about interactions between a non-native crayfish, orconectes virilis, and the native Pacifasticus. Orconectes is a widely distributed species whose native range extends into eastern Montana. It has been introduced into western Montana and deliberately dispersed by the Montana Department of Fish, Wildlife, and Parks and probably by anglers (Sheldon 1989). There is concern that orconectes may replace pacifasticus in some areas. For a complete review of this issue, see Sheldon (1989).

In March 1991, the Montana Department of Fish, wildlife, and Parks contracted with Ginger Thomas to prepare a literature review on crayfish ecology and management. The purpose of this report is to provide the MDFWP with information that will be helpful in making management decisions for the Montana commercial crayfishery.

The report covers three areas: 1. A review of the recent scientific literature concerning the population dynamics and ecology of crayfish populations with emphasis on orconectes and pacifasticus sp. Special emphasis is given to studies that have evaluated exploited populations. 2. A review of the scientific literature concerning the importance of crayfish in the diet or food chain of fish, aquatic birds and mammals, with an emphasis on Montana species and 3. A narrative and tabular summary of information concerning commercial crayfishing activities in the Pacific northwest states and provinces. 


\section{Digitized by the Internet Archive in 2017 with funding from Montana State Library}




\section{PACIFASTICUS SP. AND ORCONECTES}

Pacifasticus sp.

\section{Life history}

Pacifasticus are members of the family Astacidae, which includes many of the European crayfishes. Fertilization and egg laying take place in the autumn in response to shortening day length and falling water temperatures (Hogger 1988). In British Columbia, mating occurs when water temperatures are less than $140 \mathrm{C}$ during periods of shortening day length (Mason 1975). Eggs are carried over the winter by the female, with hatching occurring the following summer (Hogger 1988).

Pacifasticus leniusculus has a life span of from $48-132$ months and age 8+ crayfish reach a carapace length (CL) of 47 $54 \mathrm{~mm}$ (Momot 1988). However, Sheldon (1989) reported male pacifasticus exceeding $70 \mathrm{~mm} \mathrm{CL}$ in his report on western Montana crayfish populations. He also reported that most of his catch was greater than $45 \mathrm{~mm} \mathrm{CL}$, the approximate commercial minimum.

The growth rate of Pacifasticus varies with water temperature and is density dependent. However, it is clear that Pacifasticus grows faster than many other North American temperate zone species and may achieve a larger final size (Lowery and Holdich 1988). Males typically grow faster than females (Sheldon 1989, Abrahamsson and Goldman 1970). Growth rates for Pacifasticus have been studied in Lake Tahoe, California and the Sacramento River, California. Growth rates in the Sacramento River are faster, probably due to warmer water temperatures. Young-of-the-year (YOY) Pacifasticus reach an approximate carapace length of $20-27 \mathrm{~mm}$ in the Sacramento River, as compared to $15-22 \mathrm{~mm}$ in Lake Tahoe. The Sacramento River populations remain larger at a given age compared to the Lake Tahoe populations throughout their life cycle. The average molt increment in the sacramento River is $2.3 \mathrm{~mm}$, compared to 2.0 $\mathrm{mm}$ in Lake Tahoe (Shimizu and Goldman 1983, Flint 1975a). Sheldon's (1989) preliminary analysis of Pacifasticus growth rates in Montana found them to be comparable to the Sacramento River population, however the sample size was small.

The age at maturity varies depending on the growth rate. They may mature the first summer, although the second summer is more usual. In Lake Tahoe, the males mature in the third summer, and females the fourth summer (Lowery and Holdich 1988). The age at maturity may also vary from year to year within a water body, especially for females. For example, McGriff (1983) reported that the percentage of mature 2+ female Pacifasticus leniusculus varied from $80.2 \%$ in 1977 to $36.8 \%$ in 1979 in the Sacramento-San Joaquin Delta. 
The average size at maturity has been reported to be $40-50$ mm (MCGriff 1983). Flint (1975b) found a difference in the size at maturity among crayfish taken from the three transects he studied in Lake Tahoe. He attributed smaller size at maturity to lack of suitable cover for larger individuals and greater population density which resulted in a population of stunted adults. Sheldon (1989) reported only one berried female in his samples from Montana waters at the relatively large size of $63 \mathrm{~mm}$ CL. However, he comments that the biased sex ratio of this sample suggests that many berried females were inactive and unavailable to his sampling gear.

The mean number of eggs per female is 110 to 280 (Momot 1988). The mean number of eggs per female varies by the size and age of crayfish, and with the year. Larger and older crayfish tend to carry more eggs (McGriff 1983).

Pacifasticus leniusculus are reported to have standing crops from 132 to $622 \mathrm{~kg} /$ hectare (Momot 1988).

\section{Habitat requirements}

The habitat preference of pacifasticus is for slower moving streams. However, the range and diversity of habitat occupied by this genera has been extensively modified by man. They are found to occupy clear, shallow, coastal streams; reservoirs and lakes; and turbid, saline delta regions (Hogger 1988). The juveniles seem to favor fast flowing shallow regions, moving to deeper slow moving pools as they grow up (Lowery and Holdich 1988).

crayfish in general are very sensitive to changes in water quality and habitat changes, particularly as they are slow moving bottom dwellers, confined to a relatively narrow littoral zone. The crayfish is as demanding as salmonid fish in its requirements for dissolved oxygen in water. They do not thrive in waters with a $\mathrm{pH}$ value below 6.0, although they can withstand a $\mathrm{pH}$ of 4.0 and even lower for short periods of time. The ability of crayfish to withstand increases in suspended solids is little understood (Westman 1985).

Rock size is an important factor in determining crayfish density and distribution. Unlike many other species, Pacifasticus is a non-burrowing species that prefers areas which provide suitable cover. Rocky substrate provides crevices for crayfish to use as cover. Shimizu and Goldman (1983) in their study of Pacifasticus in the sacramento River found that crayfish distribution was primarily influenced by substrate. Rocky areas provided $87 \%$ of their catch, while the other $13 \%$ was taken from traps set on sand and mud-silt areas. Flint and Goldman (1977) found that the larger the crayfish, the larger the rocks used for cover. However, open sandy areas support lower numbers of crayfish but larger sized individuals. Iarger crayfish can live 
in these areas as their large size protects them from fish predation (Hogger 1988).

In regions with stones of suitable size, the animals may become so abundant that they are stunted (Lowery and Holdich 1988). Studies of crayfish from different areas of Lake Tahoe have shown that there is a large variation in the density and average body length of these animals. One transect in Lake Tahoe which had an abundant, stunted population of crayfish had a large percentage of cobble-boulder substrate, large percent of shallow water, a high level of periphyton growth, but a smaller mean rock size than other areas of the lake. High densities of crayfish on this transect caused overcrowding resulting in competition for food and suitable cover resulting in a stunted population (Abrahamsson and Goldman 1970, Flint and Goldman 1977).

In Lake Tahoe, crayfish are confined to the depth of less than $40 \mathrm{~m}$, regardless of the substrate. This seems to be because Pacifasticus eggs do not hatch at cold water temperatures. In a laboratory experiment oviferous females were held in a fluvarium from the beginning of May until mid-september without any eggs hatching. During this time the water temperature ranged from 5.8 to $8.6^{\circ} \mathrm{C}$, and averaged $6.8^{\circ} \mathrm{C}$ (Abrahamsson and Goldman 1970).

Additionally, crayfish in Lake Tahoe undertake extensive seasonal migrations. During the summer and autumn, the peak distribution of crayfish is in shallow near-shore waters. In autumn the population migrates into deeper waters. It is supposed that the migration is an adaption of the species to avoid winter storms that cause high rates of mortality among members of the population living in shallow water (Flint 1977).

\section{Orconectes sp.}

\section{Life history}

The typical orconectoid crayfish life cycle is about three or four years. Females, which move in shore in early spring, produce only one brood per year. The female orconectes virilis (the species found in western Montana) attach eggs to their pleopods in early spring, i.e. April or May. The young are usually attached for one to three weeks, and depending on temperature, hatch in May or June. The young of the year then frequent the littoral zones of lakes or ponds or the riffle areas of rivers or streams. The young remain attached to the female through two molts and leave after the second molt (third instar) (Momot 1988).

Adult males are usually larger than females of the same age. Male members of this family of crayfish come in two forms. The Form I male is sexually competent. When their post-reproductive moult occurs, the males turn into the sexually incompetent Form 
II (Hogger 1988). The mature animals usually mate in late summer or early spring. The male transfers the sperm to a receptacle in the abdomen of the female (Momot 1988). The females of 0 . virilis migrate to deeper water during the summer. This is due either to increased aggression by males or to environmental triggers to facilitate gonadal maturation. Gonadal maturation occurs only in total darkness at temperatures less than $10^{\circ} \mathrm{C}$ (Momot and Gowing 1972).

orconectes virilis has a maximum life span of 40 months. An age $3+\underline{0}$. virilis reaches a mean length $(C L)$ of $40-44 \mathrm{~mm}$. Sheldon (1989) reported catches of larger than average orconectes in McGregor Lake and Cabinet Gorge Reservoir (46 and $47 \mathrm{~mm} \mathrm{CL}$ respectively). The average growth increment has been reported to be 2.0 to $2.7 \mathrm{~mm}$ per moult, depending on age and sex (Weagle and Ozburn 1972). The mean number of eggs per female is $86-214$. Larger females generally carry more eggs. They are reported to have standing crops from 5.5 to $142.9 \mathrm{~kg}$ per hectare (Momot 1988).

\section{Habitat requirements}

The genus orconectes is considered to be tertiary burrowers. That is, they burrow only during drought conditions, and in some cases during their breeding cycle. orconectes occur in both lotic and lentic habitats under rocks, in vegetation, among the roots of riparian trees, in leaf litter and in gravel beds (Hogger 1988).

\section{Role of crayfish in the ecosystem}

\section{Trophic status}

Crayfish are polytrophic; that is they are herbivores, omnivores, and detritivores. Their diet is largely plant detritus although the main nutritional value of this food is derived from the epiphytic fungal and bacterial organisms involved in decomposition. Crayfish also eat macrophytes, invertebrates, small fish, and other crayfish. The food of animal origin usually constitutes the smallest part of the diet but it provides essential organic compounds (Hogger 1988)

The crayfish's popular image is as a scavenger. This is mainly an opportunistic role which is greatly exaggerated. Circumstances such as fish kills can make scavenging important, but in the crayfish's day-to-day role in the community it is far less important than many of its other activities (Momot et al 1978).

The position of crayfish as consumers on several trophic levels means they perform a vital function within the aquatic 
ecosystem. Crayfish biomass tends to be high relative to other consumers which can not readily utilize detritus and living vegetation so they transfer energy directly to higher trophic organisms (Hogger 1988). Not only do crayfish utilize the microorganisms in detritus, but they also break it down into finer particles more easily attacked by decomposers. Crayfish could also be considered to be acting as decomposers (Momot et al 1978).

Without crayfish, much of the energy in the food cycle would be short-circuited into dead ends leading to an overall decrease of energy cycling, community productivity, and food availability to higher trophic levels in the system (Momot et al 1978).

However, it should be noted that the role of crayfish in the ecosystem varies by the species of crayfish. In wisconsin, the introduction of the rusty crayfish (orconectes rusticus) into waters where it was not native has resulted in a short circuiting of the ecosystem. The rusty crayfish consume the plants that fuel the production of insects and small fish. In addition, rusty crayfish also feed on the remaining snails and insects. Through the consumption of those invertebrates and of fish eggs, as well as destruction of habitat, crayfish are replacing small fish, and ultimately bass, walleye, and muskellunge as the top predators. Much of the problem with rusty crayfish comes from its very agressive behavior which makes it a difficult prey item for fish (Lodge at al 1985).

Crayfish tend to be most important in lakes with low phytoplankton production. In such lakes, detritus and benthic algae, both of which are ingested by crayfish, are important sources of energy. Since crayfish are a major consumer of benthos, they provide a key link in the food web by interacting with species ranging from large benthic invertebrates and submerged higher aquatic plants and animals to the periphytic microcommunity. In low nutrient lakes, due to their functional role and biomass dominance, the role of crayfish is more significant than is assumed from their occurrence in fish diets (Momot et al 1978).

Crayfish can also have an impact on the behavior of other animals in their environment. Rahel and stein (1988) report that johnny darters (Etheostoma nigrum) were more active in the presence of smallmouth bass and crayfish than they were in the presence of bass alone. Crayfish increased the vulnerability of darters to bass by evicting them from shelters and causing increased activity. Conversely, bass increased the vulnerability of darters to crayfish by forcing them to seek cover under shelters occupied by crayfish.

\section{Impact on aquatic vegetation}


Crayfish have an impact on their environment. There is considerable documentation of crayfish reducing the abundance of aquatic macrophytes. The introduction of Pacifasticus into a previously crayfish free water resulted in a significant

reduction of aquatic macrophytes in England (Hogger 1984). The same phenomenon was reported by Taub (1972), who observed that plant growth during his study of a small ohio pond was inversely proportional to crayfish density. In Wisconsin, densities of rusty crayfish of one per square yard - a density often exceeded in nature- reduced the biomass of aquatic plants by $40 \%$ (Lodge et al 1985).

There has been some interest in using crayfish as a biological control for aquatic weeds. Dean (1969) found that the crayfish orconectes causeyi is useful in controlling submerged aquatic plants in shallow trout lakes in the southwestern united states. This control is probably self-limiting however, as crayfish use plants not only for food but also for cover. If the plant density is reduced too far, then predation on crayfish increases (Saiki and Tash 1979). In addition, emergent shoreline vegetation serves as a nursery area for newly hatched orconectes virilis. A decrease in vegetation could result in lower recruitment (Momot and Gowing 1983).

An over abundance of crayfish can result in increases in turbidity from the lack of vegetation and from crayfish activity. Increased turbidity can, in turn, reduce the photic zone and increase the rate of absorption of solar energy. These effects may offset each other (Rickett 1974).

In Sweden, lakes which lost crayfish populations to plague suffered increased eutrophication and growth of aquatic macrophytes (Abrahamsson 1966, Abrahamsson 1973).

Crayfish must be above a certain density before vegetation is reduced. Below this density, grazing may actually increase plant growth (Lorman and Magnuson 1978).

clearly, the ideal situation is to maintain a balance between crayfish densities, vegetation, and the predator population.

\section{population dynamics of exploited populations}

The effect of exploitation on wild crayfish stocks has been examined with regard to orconectes virilis in two sets of lakes, North Twin and West Lost Lakes, Michigan and Dock and shallow Lakes, ontario (Momot 1985). In the Michigan study, the two populations were managed using the maximum sustained yield model (MSY) (Ricker 1975). After harvesting all crayfish greater than $6 \mathrm{~cm}$ TL with traps at the MSY rate for three years, fishing effort was then increased four-fold in West Lost Lake for two 
successive seasons, while in North Twin Lake the MSY was retained.

In West Lost Lake, yields were stable during MSY, but increased with over-exploitation during which both growth and recruitment declined. Distortions then occurred in the age composition of the population. In North Twin Lake, this same pattern was repeated even though the population was fished at the prescribed MSY rate. In the last year of the fishery the catch drastically declined even though harvest had not been increased over the MSY. Because of a dramatic decrease in recruitment, North Twin had been greatly over-fished by 1975 (the last year of the study).

The assumption of relatively constant recruitment of the Ricker model was not met. Decreased recruitment in both lakes was attributed to two factors: 1. a decrease in the survival of hatchlings in both lakes due to a loss of nursery habitat caused by natural factors and 2. an increase in the density of sub-adult females as a result of the fishery being mainly directed toward males over $6 \mathrm{~cm}$ TL. There is also a possibility that the predation by sub-adult male and female crayfish on young may have been a factor as well.

Yields were not a good indicator of the impact of the fishery since yields in North Twin remained high just prior to the collapse (Momot 1988).

The experiment on the ontario lakes was somewhat different as these two lakes are eutrophic. Nutrient rich lakes were selected so that a density-dependent growth response could be documented. In addition the low oxygen content of the deep waters of Dock Lake kept female crayfish confined to shallow waters. This avoided the problem of selective harvest of males. Shallow Lake was left unexploited in this experiment.

In the Dock Lake experiment, yields remained steady and increased with effort. Production increased through a shift in survival rates and age at maturity to compensate for the increased rate of removal. The question remains as to how much more of the stock can be harvested without causing a sudden stock collapse (Momot 1988).

While fin fishes typically respond to exploitation through a growth or fecundity adjustment, crayfish adjust to exploitation principally through a shift in survival rates and age at maturity. Both of these responses are much more difficult to estimate (Momot 1988). The absence of dramatic density dependent compensation in growth and a limited fecundity response inhibits early detection of growth over-fishing in orconectid crayfish populations, especially in northern latitudes. If such populations were subjected to a succession of years exhibiting 
poor climatic conditions for optimum cohort recruitment, wide oscillations in production and yield might result. Since growth over-fishing cannot be easily detected, recruitment over-fishing remains a distinct threat.

McGriff's (1983) study of the crayfish (Pacifasticus leniusculus) of the Sacramento- San Joaquin delta confirms that crayfish tend to adjust survival rates and age at maturity in response to higher mortality. Both 1976 and 1977 were severe drought years in California. The data indicate that the 1976 and 1977 year classes may have been weakened by decreased survival of juveniles during the adverse conditions. The 1978 year class compensated for the decreased fecundity during the drought with increased survival of juveniles when conditions improved. In addition, although significantly fewer eggs per female were produced in 1977, there was a higher level of maturity among smaller sizes and younger ages that year. Therefore, the absolute fecundity level, in total eggs produced Delta-wide, may not have been reduced. Commercial fishing does not seem to have had an impact on the fecundity of the Delta population (McGriff 1983).

Crayfish management has been of interest to the Swedes for many years as crayfish are a favored food in Sweden. Svardson (1949) examined whether the stunted crayfish (Astacus fluvialtis) population of Lake Alkvettern, Sweden was due to overfishing, overpopulation, or genetic growth capacity. He concluded that the small size of the population was due to overpopulation. He based his conclusions on evidence of slow growth of the Lake Alkevettern population, and faster growth when crayfish from this lake was transplanted to other lakes. His recommendation to increase the size of the crayfish was to increase harvest of the smaller crayfish, or to re-introduce eels, which prey on crayfish. However, he does not report if his recommendations were acted upon or whether they were effective in increasing the average size of crayfish.

Catch per unit effort is not a reliable indicator of population density. In a study of Donner Lake and Lake Tahoe, Goldman and Rundquist (1977) found through mark and recapture studies that Lake Tahoe had a higher density of crayfish than Donner Lake. However, based on the average catch/trap data alone, one might conclude that the two populations were very similar. Predator density is one factor that influences trapability. Rock bass in particular have been found to reduce the trapability of crayfish (Collins et al 1983).

It should be noted that commercial harvesting of crayfish is size selective. Since large individuals are more herbivorous and less carnivorous than small individuals, changes in the population structure could modify the role of crayfish population in the system (Lorman and Magnuson 1978). 


\section{Summary}

The population dynamics of exploited populations is not well understood. The quantitative research done to date has been primarily on orconectes populations. Several generalities can be made. Crayfish populations tend to respond to exploitation through a shift in age at maturity and survival rates. These changes are relatively difficult to detect. Catch per unit effort is not a reliable indicator of population density. Catches can remain high until the population collapses. Crayfish populations are sensitive to environmental conditions which makes accurate calculation of MSY difficult. In addition, commercial harvest of crayfish is sex selective in most situations. This can result in unexpected changes in the structure of the population.

However, this information comes primarily from experimental research. In actual commercial crayfisheries, such as in oregon and California, no substantial biological problems have been noted.

\section{IMPORTANCE OF CRAYFIBH AS FOOD FOR OTHER BPECIEB}

Crayfish are preyed upon by a wide range of organisms of both terrestrial and aquatic origin. Rarely do they form more than a minor part of the overall diet of the predator. The most vulnerable periods are the juvenile stages and the immediate post-molt period when the exo-skeleton is still soft. The importance of crayfish as a food is often seasonal (Hogger 1988).

\section{Trout}

\section{Brook trout}

Benson (1953) studied eastern brook trout (Salvelinus fontinalis) food habits from April to september 1952 in the Pigeon River, otsego County, Michigan. The frequency of occurrence of crayfish in brook trout stomachs varied from $3.2 \%$ (June 24 to July 4) to 35.1\% (May 24 to June 6). The percent composition of crayfish in the stomachs varied from $0.4 \%$ (July 19 to Aug 1) to 39.8\% (May 24 to June 6). Mayflies and caddisflies tended to have a higher frequency of occurrence than crayfish, but crayfish were clearly an important component of the diet in terms of the volume of food.

Larger brook trout (over 9" in length) were found to feed heavily on crayfish in West Lost Lake, Michigan in the late summer (July - October) and winter (December - March). Trout were effective predators only on $1 / 2$ to 1 year old crayfish. Apparently crayfish more than a year old were too large to be captured by trout. It is believed that crayfish were more available to trout in these two seasons for the following 
reasons: 1. in the spring the crayfish young-of-the-previous-year were larger than the maximum size consumed by trout, 2 . the young-of-the-present-year had not yet hatched and were unavailable to trout in the spring and 3. in the fall, trout eggs were more important in the trout diet. Brook trout under 9 " were found to feed on crayfish only sporadically and in small amounts (Momot 1965, Momot 1967).

On an annual basis, brook trout utilized only $2.9 \%$ of the total net production of crayfish biomass in West Lost Lake (Momot 1965, Momot 1967). In this lake, trout predation acted as a compensatory form of mortality in that trout ate crayfish that would have died of other causes. Trout predation had no impact on the crayfish population (Gowing and Momot 1979).

Rainbow trout

Predation of rainbow trout (oncorhynchus mykiss) on crayfish (orconectes virilis) was studied from 1983 to 1985 in Newcastle Reservoir, Utah. This predation was found to be seasonal, occurring only during June-December. It was greatest during June - August, when up to $100 \%$ of fish stomachs contained crayfish. Crayfish were consumed up to a size of $38 \mathrm{~mm}$ in carapace length (CL). Relative sizes of predators and prey helped limit crayfish consumption by fish, but seasonal behavior and distribution of crayfish also influenced their availability. Rainbow trout growth declined after crayfish became abundant in the reservoir. Crayfish changed the reservoir ecosystem by altering the food web and thereby reducing the energy transfer to trout (Hepworth and Duffield 1987).

Parson (1955) studied food habits of rainbow trout in a tail water fishery below Dale Hollow Reservoir. He found that algae and associated organisms and snails were the most important food for all sizes of trout. Terrestrial insect forms and crayfish were more common in larger trout than smaller trout. Of the rainbow less than 12 " in length, none had crayfish, but $11 \%$ of the rainbow greater than 12" had crayfish in their stomachs.

There were sharp differences in the consumption of crayfish by rainbow trout from year to year in Birch Lake, Michigan. Crayfish and scuds were $3 \%$ of the diet over a six year period, but were completely absent from the stomachs from 1941-1943. Rainbow under 12" only occasionally utilized crayfish, whereas $10 \%$ of the rainbow trout over 12" contained crayfish. The average number of crayfish per stomach was 1.5 , with the maximum number being 8 per stomach (Leonard and Leonard 1946).

\section{Lake trout}

A study of the food of lake trout (Salvelinus namaycush) in 
Lake Tahoe (Frantz and Cordone 1970), found that crayfish (Pacifasticus leniusculus) were the only invertebrate that is of importance in the diet of larger lake trout. Crayfish were not found in the stomachs of lake trout smaller than 10.0" (FL). Lake trout stomachs from fish 10.0" to 14.9" contained 2.0\% crayfish by weight ( $3.3 \%$ frequency). Crayfish were more common in the lake trout from 15.0" to 19.9": 12.6\% frequency, 11.7\% by weight. Lake trout over 19.9" contained 8.8\% crayfish by weight, $17.1 \%$ frequency.

The importance of crayfish in the diet varied seasonally. Generally, crayfish were utilized most heavily in the summer. The exception to this is the 10.0 to 14.9 " lake trout which utilized crayfish more heavily in the spring (5.7\% frequency, $2.6 \%$ by weight) than in the summer (2.9\% frequency, $0.4 \%$ by weight). This size class of lake trout utilized crayfish lightly in the autumn (2.0\% frequency, $2.1 \%$ by weight), and not at all in the winter. The other size classes utilized crayfish moderately and in approximately the same amounts in the spring and fall, and the least in the winter. The highest percent frequency of occurrence was with lake trout over 19.9" in the summer ( $30 \%$ frequency of occurrence, $19.8 \%$ by weight). For this size class and season, crayfish were the second most important food.

Not surprisingly, the mean and maximum length of the crayfish ingested increased with size of fish. The mean length of the crayfish ingested by the 10.0" to 14.9" fish was 1.6", with the maximum length being 1.8". Lake trout over 19.9" ate crayfish of a mean length of 2.9", with a maximum size being 4.3" (Frantz and Cordone 1970).

In contrast, lake trout in Birch Lake, Michigan were not found to be feeding on crayfish (Leonard and Leonard 1946).

\section{other trout}

Neither brown trout (Salmo trutta) nor cutthroat trout (oncorhynchus clarki) were found to contain crayfish in a study of food habits of $f$ ish in the Pend oreille River (Barber et al 1990)

Lowery (1966) did find crayfish in the diets of cutthroat trout, but their occurrence was limited to a short period of time in the spring. The sample taken on May 18 found $19.6 \%$ occurrence by dry weight. The sample taken June 1 found $46.2 \%$ occurrence by dry weight. None of the other samples taken contained crayfish. The author noted that the June 1 sample contained larger fish than any of the other samples, in line with the observation that larger fish tend to utilize crayfish more heavily than small $\mathrm{f}$ ish. 
Leathe and Graham (1982) did not detect crayfish in the diets of $\mathrm{fish}$ in Flathead Lake, Montana.

\section{Iargemouth bass}

Dubets (1954) studied the food habits of largemouth bass in four lakes in Illinois. In lakes that contained gizzard shad, this was the most popular food item and the frequency of occurrence of crayfish was low ( $1 \%$ to $10 \%$ of the fish contained crayfish). However, in Christopher Reservoir, which did not contain gizzard shad, crayfish was the most popular food item. of the 12 stomach examined from this lake that contained food, $50 \%$ contained crayfish.

A study of the food habits of largemouth bass from crab orchard Lake, Illinois found that the most important food item was gizzard shad. Crayfish were found in $15 \%$ of the stomachs. only $10 \%$ of the fish contained more than one forage item. of the fish that did contain more than one forage item, $46 \%$ contained at least one crayfish (Lewis et al 1974).

Snow (1971) found an average of 1.4 crayfish per bass stomach and 1.2 fish per bass stomach in Murphy Flowage, Wisconsin. There were no gizzard shad in this lake.

Lewis et al (1961) in their study of the food choice of largemouth bass as a function of availability and vulnerability of food items, found that the utilization of crayfish was quite variable. In some trials, crayfish were not used at all, while in two trials crayfish were preferred to bullfrogs and tadpoles. In their tests, golden shiners seemed to be the preferred prey. Largemouth bass also preferred leopard frog tadpoles to crayfish. Green sunfish and bullfrog tadpoles were eaten in preference to crayfish in one trial, but in another trial they were eaten only $50 \%$ as well.

Crayfish (Pacifasticus sp.) were found in the stomachs of age $3+$ largemouth bass during the summer in Lake Pend oreille (Barber et al 1990). However, they were only in $2.3 \%$ of the stomachs examined for this age class of fish. No other age class of largemouth bass were found to be eating crayfish, and no age $3+$ bass were found to be eating crayfish during the spring and fall.

An interesting study of crayfish-largemouth bass interactions in a small ohio pond was done by Taub (1972). this study, a small pond was located which contained large populations of the burrowing crayfish cambarus diogenes, and no fin fish. An estimate of the crayfish population at the start of the study found an estimated population of 37,000 crayfish \pm 2,000 at the $95 \%$ confidence level. 
Largemouth bass were then stocked at a rate of 770 per hectare. Attempts to estimate the crayfish population during the two years after bass were introduced were unsuccessful due to the low density of crayfish. However, largemouth bass continued to utilize crayfish as prey throughout the course of the study despite their low numbers in the pond. In the first year after bass introduction, $69 \%$ of the bass stomachs contained crayfish. During the second year this dropped to $54 \%$. Largemouth bass growth was good throughout the study.

The author comments that it was surprising to find even moderate use of crayfish by bass after 24 months because seining indicated a low crayfish population 12 months after the bass introduction. This suggests that largemouth bass are highly effective predators of crayfish. These results should be applied with caution in Montana however, since the species of crayfish in this study is a burrowing crayfish (Taub 1972).

Mullan and Applegate (1970) studied the food habits of largemouth bass during the filling of Beaver Reservoir. Bass smaller than $100 \mathrm{~mm}$ TL did not utilize crayfish. Bass that were $101 \mathrm{~mm}$ to $200 \mathrm{~mm} \mathrm{TL}$ ate crayfish in small amounts during the spring and fall (percent of total volume varied from $1.2 \%$ in November to $14.2 \%$ in April).

Bass larger than $200 \mathrm{~mm}$ TL ate crayfish during the winter, spring, and fall. The percent of total food volume made of crayfish varied considerably from month to month. Crayfish were not utilized in the summer months (June, July, August). During the other 9 months crayfish composed from 1.3\% of the total food volume (January) to $71.9 \%$ of the total food volume (September). The authors stated that as young shad diminished in abundance and in stomach contents as the summer progressed, largemouth bass larger than $200 \mathrm{~mm}$ TL included more crayfish in their diet.

This differs somewhat from the result of the research done by Rickett (1974). He found bass as small as $41 \mathrm{~mm}$ utilizing crayfish, although bass larger than $100 \mathrm{~mm}$ ate crayfish more frequently than did smaller bass.

\section{Smallmouth bass}

In Lake Sammamish, Washington, the major prey of smallmouth bass (Micropterus dolomieui) were juvenile salmon, crayfish, and sculpins. The young smallmouth bass fed primarily on smaller versions of the same prey types that the adults fed on, rather than different food types. The number of juvenile salmon in smallmouth bass stomachs was highest in May, during the peak of the salmon out migration. In the other months studied (March through August), crayfish and sculpins were the most important food. Smallmouth bass in Lake Sammamish are apparently feeding generalists, feeding on prey items as they are encountered. The 
more numerous the prey is in the environment, the more numerous it is in the stomachs (Pflug and Pauley 1984).

Investigations of smallmouth bass food habits in Dworshak Reservoir, Idaho, found decapods to be a small portion of the diet ( $7.7 \%$ frequency of occurrence, $9.3 \%$ by volume) (Statler 1990).

Emery (1975) concluded that stunting of a smallmouth bass population in Lake opeongo, Ontario, was the result of competition with cisco (Coregonis sp.) and a limited supply of crayfish for adult bass. The average intake of food items on a volume basis was $69.1 \%$ crayfish over the years of the study. The range of values was $38 \%$ in 1956 and $74 \%$ in 1971 . He estimated that bass constitute a mortality factor of approximately $70 \%$ on orconectes sp., as compared to an overall mortality rate of $75.5 \%$. It appears that bass are responsible for a major part of the mortality of orconectes in this system.

\section{Emery (1975) also noted competition for crayfish between} divers and smallmouth bass. Bass took the crayfish as the SCUBA divers chased them in an attempt to capture them for the research project. He also said that the bass could easily be fed 10 crayfish from a diver's hand. Up to 5 crayfish per stomach and an average of 2.5 crayfish per stomach were found in bass stomachs in 1972. Smallmouth bass showed a distinct preference for orconectes over Cambarus in this lake. This may be due to bass being crepuscular feeders, and cambarus are primarily active at night. orconectes is relatively active in the daytime, and is quite active at dusk when the bass are feeding.

Other fish

Maloney and Johnson (1955) studied the food habits of walleye (Stizostedion vitreum) and yellow perch (Perca flavescens) in two Minnesota lakes. Food of young of the year walleye was almost entirely fish in both lakes. Young of the year perch fed on plankton crustaceans and insects. In Mille Lacs Lake yearling yellow perch ate $24 \%$ crustaceans, including hyalella, cladocerans, and a few crayfish. In Lake

Winnibigoshish yearling yellow perch ate crustaceans and insects in late June but by late July crustaceans had been replaced by fish.

Jeppson and Platts (1959) commented that perch fed mostly on crayfish and insects in the three northern Idaho lakes they studied. In Cocalella Lake, $98 \%$ of the perch food volume was crayfish. In Lake Pend oreille, none of the perch had eaten crayfish, all of the perch were eating insects. In Hayden lake, $87 \%$ of the perch food volume was crayfish.

Bonde and Maloney (1960) studied winter food habits of 
burbot (Lota lota) in Mille Lakes, Minnesota. In 1949, 4.2\% of the burbot contained crayfish. In 1958-59, 9.4\% of the burbot contained crayfish. The primary winter food of burbot was found to be perch, with darters, cyprinids, sculpins, crayfish, and mayflies of secondary importance.

Burbot were also reported to feed on Cambarus at night in Lake opeongo, Ontario (Hackney 1973).

A study of the food habits of northern squawfish (Ptychocheilus oregonensis) in northern Idaho found that 8. 1" to $12.0 "$ squawfish contained $30 \%$ crayfish by volume. The 16.1" to $20.0 "$ squawfish contained $6 \%$ crayfish by volume. other sizes of squawfish did not contain crayfish (Jeppson and Platts 1959). However, the importance of crayfish in the diet varied considerably between lakes. In Hayden Lake, 18\% of the squawfish food volume was crayfish, whereas in Lake Pend oreille only $1 \%$ of the squawfish food volume was crayfish. In Lake Cocalalla squawfish were not found to eat crayfish.

A study of the fisheries of Lake Roosevelt, Washington did not find crayfish to be an important food item in the diet of any of the fishes reviewed. No crayfish were found in the stomachs of lake whitefish (Coregonis clupeaformis), northern squawfish, or yellow perch. A small percentage of the walleye stomachs contained crayfish during July (1.9\% frequency of occurrence, 0.8 $\%$ by weight and volume), but not during May, June, August, or september (Nigro et al 1983).

Observations of the food habits of $f$ ish in the clark Fork River, Montana indicates that crayfish are an important component of the diet of northern squawfish (Berg pers. comm. 1991). However, the study was limited to spring time food habits, primarily the month of May.

In Nigro's (1990) study of the status and habitat requirements of the white sturgeon (Acipenser transmontanus) in the Columbia River downstream from MCNary Dam, he found that $17.2 \%$ of the white sturgeon stomachs contained Pacifasticus sp. The number of Pacifasticus sp. in the stomachs varied from 1 to 17, with the mean being 3. Pacifasticus comprised $26.5 \%$ of the food volume by weight.

A study of the food habits of the fish of the Pend oreille River found crayfish in the stomach of $100 \%$ of the age $7+$ yellow perch in the summer (Barber et al 1990). However, the sample size was only one fish. They found no crayfish in the stomach of any other yellow perch during any other season. They also did not report crayfish being utilized by mountain whitefish (Prosopium williamsoni), black crappie (Pomoxis nigromaculatus), kokanee (Oncorhynchus nerka), pumpkinseed (Lepomis gibbosus), tench (Tinca tinca), largescale sucker (Catostomus macrocheilus), 
long nose sucker (Catostomus catostomus), northern squawfish, peamouth (Mylocheilus caurinus), or black bullhead (Ictalurus melas).

Allen (1939) studied the food habits of pike in Lake Windermere and found they fed almost exclusively on fishes, mostly perch.

Black bullheads (Ictalurus melas) were found to consume crayfish by Rickett (1974), although they preferred artificial fish food, vegetation, and mayfly nymphs.

Wading birds

The principal avian predators on crayfish are wading birds such as ibises, herons, and egrets. As much as 90 - $95 \%$ of the diet of yellow crowned night herons (Nyctianassa violacea) consists of crayfish, whereas they comprise 45-50\% of the diet of the little blue heron (Florida caerulea) (Huner and Barr 1984).

Collazo (1985) studied the food habits of great blue herons in Idaho. He found that the primary food were brown bullheads (Ictalurus nebulosus) and tench. Only one crayfish was found in a great blue heron stomach over a two year study.

\section{other birds}

Ducks will occasionally eat crayfish. Kimble and Ensminger (1959) mention crayfish as ranking 13th in importance in the diet of ducks (out of 15 items) in Louisiana after a hurricane. Ducks $W^{\wedge} U^{\wedge} \wedge$ not reported to be eating crayfish prior to the hurricane.

Crayfish play an important role in the diet of eastern belted kingfishers (Megaceryle alcyon alcyon) during a short period during the young bird's development. After learning to catch insects, young kingfishers spend the 5 th to the 10 th day on the wing exclusively learning to capture crayfish. Broods in this period show a striking uniformity of behavior. It is the latter part of the second week on the wing when kingfishers learn to catch fish. The frequency of occurrence of crayfish in the diet of kingfishers was found to vary from 14.3\% (on trout rearing waters) to $59.1 \%$ on non-trout streams

(Salyer and Lagler 1946). Kingfishers seemed to eat more crayfish from streams than from lakes, perhaps due to the greater proportion of shallow water in streams.

Eipper (1956) studied the food habits of eastern belted kingfishers and found that crayfish composed $49.5 \%$ of the remains from two kingfisher nests. Orconectes made up two-thirds of the stream samples, but was not found in nests remains. The nests remains were $100 \%$ Cambarus. The reason may be that Cambarus breeds in both the spring and fall. The spring breeding 
behavior may increase the crayfish's vulnerabilty to kingfisher attack.

Bald eagles will occasionally eat crayfish, although they do not constitute a major portion of the diet (Becker 1991 pers. comm.)

Mink

Mink (Mustela vison) tend to be opportunistic feeders with a varied diet (Linscombe et al 1982). Crayfish are frequently used by mink. Korschgen (1958) stated that crayfish occurred in mink stomachs $19.9 \%$ of the time ( $9.3 \%$ of the food volume by weight) during the winter in Missouri. He noted that mink predation on crayfish increased during drought periods, which made crayfish more available to mink. In addition, crayfish were more common in mink stomachs taken from southern Missouri than those taken from northern Missouri. Waller (1962) found crayfish more abundant in scats collected during summer and fall months and in areas where crayfish were most plentiful. crayfish constituted $22.3 \%$ of the food of mink in summer in an Iowa marsh (Waller 1962). Erlinge (1969) did not mention crayfish as being a component of the diet of mink in Sweden. However, he does state that he observed mink catching more prey, including crayfish, than they immediately require and then storing it.

Gerell (1967) studied the food habits of mink in Sweden and found that crayfish were found in the diet primarily in the warm months. The low activity and more hidden mode of life in the cold months kept crayfish less vulnerable to predation. In August 1963, the crayfish were killed by the crayfish plague. In the first half of August 1963, crayfish amounted to $85 \%$ of the mink diet. In the second half of August this number went down to $31 \%$, and then by september to 0 . After the crayfish plague killed off the crayfish, mink switched to rodents and frogs for food.

Burgess and Bider (1980) studied the effects of stream habitat improvements on invertebrates, trout populations, and mink activity. They found that habitat improvement resulted in trout population and biomass increases. Crayfish (Cambarus bartoni) biomass was also greater in the improved section. Mink activity was $52.5 \%$ higher in the area surrounding the improved section. However, mink did not respond to the trout biomass increases, nor was mink activity correlated with activity patterns of any terrestrial prey species. Analysis of mink scats revealed that crayfish occurred in $20 \%$ of all scats found, and $50 \%$ of those from the study area. Thus, habitat improvement and the resulting increases in crayfish production resulted in greater use of that area by mink.

Raccoon 
Raccoons are omnivorous and opportunistic feeders. Hundreds of species of plant and animal food have been recorded from scats and stomachs, and the relative proportions of different foods vary with the locality and season. In most habitats, plants are generally more important than animals in the raccoon's diet. The most important animal food is crayfish (Kaufmann 1982).

Raccoons in most habitat throughout their range follow the same general pattern of diet changes. Only in the spring do most raccoons eat more animal food than plant food. Crayfish are the most important food at this time, followed by insects and small vertebrates. In the summer raccoons eat primarily fruits, but crayfish continue to be the most important animal food item (Kaufman 1982). Dearborn (1932) found that crayfish made up 59\% of the summer diet in one area of Michigan. Dorney (1954) found that muskrats and crayfish provided most of the diet in a Wisconsin marsh.

\section{River otters}

Most authors have found the primary food of river otters (Lutra canadensis) to be fish. However, the importance of food items other than fish should not be underestimated. Liers (1951) reported that captive otters fed a basic diet of live fish often did poorly.

Several authors have reported that crayfish is the second most important food for river otters (Knudsen and Hale 1968, Hamilton 1961, Ryder 1954, 1955). Lauhachinda and Hill (1977) report that fish were the most important food, with crayfish recovered from $62.5 \%$ of the digestive tracts that contained food remains, and $58.3 \%$ of the scats. Their study was of river otters in Alabama and Georgia.

In Montana, Greer (1955) did not identify crayfish as being in the diet of river otters in the Thompson lake region, however, it is not clear if those lakes contain crayfish. This is the only food habits study reviewed by Toweill and Tabor (1982) that did not list crayfish in the diet of otters.

The importance of crayfish in the diet of otters varies seasonally. In a study of Wisconsin otter scats, crayfish were most common in summer and winter, and least common in spring (Knudsen and Hale 1968).

other mammals

Coyotes have been reported to consume crayfish in trace amounts (Korschgen 1957). 
From the above information it is clear that the importance of crayfish in the diet of fish, birds, and mammals varies by season, species of crayfish, geographic location, year, and availability of other prey. Some generalizations can be made however. Many species of fish, birds, and mammals have been reported to eat crayfish, but there does not appear to be any species which feeds exclusively on crayfish in all localities. Large fish utilize crayfish more than small fish. Small crayfish, and crayfish that have recently molted are more vulnerable than large, hard shelled crayfish. In cold climates, crayfish are usually most important as a prey species during the summer when they are more active and therefore more vulnerable.

Crayfish can be extremely important in fish diets in some localities. In particular, yellow perch and largemouth and smallmouth bass have been reported to utilize crayfish in large amounts. The importance of crayfish in fish diets varies greatly by location and seems to depend primarily on what other sources of food are available. Trout also utilize crayfish in their diet in some locations. Even lake trout, primarily considered to be fish eaters, will utilize crayfish in some situations. Other species of fish reported to utilize crayfish include burbot, northern squawfish, black bullheads, and white sturgeon.

The primary avain predators on crayfish are wading birds such as ibises, herons, and egrets. Ducks and bald eagles will also take crayfish occasionally. Eastern belted kingfishers feed on crayfish, especially during the second week of life.

Mink and raccoons seem to be the primary mammalian predators on crayfish. However river otters will also use crayfish seasonally if they are available. Even coyotes make take an occasional crayfish. This list of species which utilize crayfish as a food source is not necessarily exhautive, but rather summarizes the most important predators and gives a picture of the range of animals that utilize crayfish.

\section{MANAGEMENT OF PACIFASTICUS SP. IN THE WESTERN UNITED STATES AND CANADA}

\section{Montana}

The 1991 Montana commercial crayfishing regulations require that commercial crayfish anglers have a Class B commercial fishing license (cost : $\$ 200.00$ ) and post a $\$ 1,000.00$ corporate surety bond. Usually only one commercial crayfish permit is issued for each body of water. However, the Montana Department of Fish, Wildlife, and Parks (MDFWP) may issue additional permits on other waters if the aquatic resource or recreational use of the water will not be affected. The MDFWP may also close waters at any time, after demonstrating the need to protect the aquatic resource, recreational use, or to protect human health and 
safety.

There are no season restrictions in Montana. The minimum size for harvest of Pacifasticus is $35 / 8$ inches and for ocronectes the minimum size is 3 inches. Undersized and berried females must be returned to the water immediately following the emptying of any single trap or trap line.

There are restrictions on the type of gear that may be used on the frequency with which the gear must be tended. All gear must be disinfected before it can be used. In addition, all traps, rings and live cars must be marked with the angler's name, address, and permit number.

The angler is required to submit monthly reports on his operations and transacions.

\section{Idaho}

About 3 to 4 years ago, there was a great deal of interest in commercial crayfish harvest in Idaho. At that time, Idaho added crayfish to the commercial fishing regulations. It now cost $\$ 100.00$ to get a commercial crayfish license in Idaho, and each trap must be marked with an identification tag which costs $\$ 1.00$ per pot. There is a $35 / 8^{\prime \prime}$ minimum size limit and reporting requirements. Since these regulations have been implemented, there has been a decline in the number of people interested in crayfishing. At this point the fishery is limited to "serious" anglers, with the casual operator being discouraged by the license cost (Van Vooren, per. comm. 1991).

There are currently about 4 anglers fishing for crayfish in Idaho. Most of the crayfishing activity is confined to reservoirs on the main stem of the snake River. Idaho has not conducted any studies of the impact of the crayfish fishery, but I was told that their qualitative observation is that there has been a downward shift in the size and age structure of the population. It is Idaho's view that the impact of this shift is probably either neutral or beneficial to the fishery. Larger numbers of small crayfish provide more available prey for the coolwater species that inhabit these waters (Van Vooren pers. comm. 1991).

Idaho has had minimal problems with non-target species being caught in the traps. There has been a little incidental catch of yellow perch or bullheads but not enough to cause a concern. There have been some enforcement problems with traps being stolen. Overall, the number of complaints they have received from other user groups has declined since the regulations went into effect.

Al Van Vooren's advice to Montana officials is to charge a 
substantial fee for the commercial crayfishing licenses to weed out the irresponsible or non-serious anglers.

\section{washington}

Prior to 1990 , there were 26,000 pounds of crayfish harvested commercially in Washington each year. Washington requires that each angler obtain a $\$ 50.00$ shellfish pot license for commercial crayfish harvest. The state publishes a list of waters that are open to commercial harvest. The general regulation is a limit of 400 pots per angler but each body of water has a maximum pot number which may be less than 400 per angler (Wood pers. comm. 1991).

The minimum size of crayfish is $31 / 4^{\prime \prime}$ from the tip of the rostrum to the tip of the tail. Undersized and berried females must be released. In the columbia River and its tributaries the season is early April to the end of october. In the rest of the state the season is May to october. There is no bag limit.

Sometimes anglers will want to harvest crayfish in a water body that is not on the list of open waters. They may apply for a commercial crayfish permit which will be reviewed to determine if there are potential conflicts such as high recreational use. If the conflicts are determined to be low, then a permit may be issued, usually for specific areas within the water body.

Anglers must fill out a crayfish log and submit the log monthly. There is no mesh size or size limit on the pots. A buoy brand number (issued by the state) and the angler's name must be put on unattended pots. Buoys must be of indestructible material and the number of pots held by each buoy must be recorded.

The fishery in washington has not gotten alot of attention. The biologist I spoke with was not aware of any over-fishing problems. He stated that their system has been pretty successful in mitigating the conflicts between user groups. He also stated that their fishery seems to be a lot of work for the number of pounds harvested and there is a lot of turnover among the anglers. It is also a lot of administrative work for the staff (Wood pers. comm. 1991).

\section{Oregon}

Oregon has a large and active commercial crayfish fishery, managed by the oregon Department of Fish and Wildiife. The statewide season in Oregon is April 1st to october 30th. The reason for this season is that is when the crayfish are catchable. Their regulations require that anglers use pots or rings only. There is no size or number restriction on traps. Most anglers fish a maximum of 80 to 100 pots per person per day. 
They have a minimum size limit of $35 / 8$ " measured from the tip of the bony spike to the tip of the telson. The reason for this size limit is that most females have spawned at least once by the time they reach that size. All berried crayfish must be released and possession of berried females is illegal (Smith pers. comm. 1991).

oregon requires that all fishing gear be identified with an identification tag. This includes boats, buoys, live boxes, bags, etc. The purpose of this regulation is to aid law enforcement and also to protect the angler in case of theft.

The entire state is open to commercial crayfish harvest except for a few areas which have been closed due to conflicts with sport crayfishing or sport trout fishing. They occasionally get complaints from sport crayfishers about the activities of commercial crayfishers, but there do not appear to be too many other conflicts (Smith pers. comm. 1991).

oregon monitors the commercial crayfishery by requiring anglers to report their catch to the oregon Department of Fish and Wildlife when the crayfish are sold commercially. The report must state the number of pounds harvested by water body. In the case of large rivers, the location of the catch must be

identified. Anglers are required to purchase a commercial fishing license (price $\$ 40.00$ ), but they do not need a commercial boat license. There is no restriction on the number of licenses issued (Smith pers. comm. 1991).

It was the opinion of the biologist from the oregon Department of Fish and Wildlife that I spoke with that the minimum size restriction is adequate to protect the fishery. He was unaware of any over-fishing problems that had occurred. He said they do occasionally get complaints from the commercial anglers that certain specific areas are being fished too heavily and they occasionally request entry limitations. Oregon has only recently begun collecting data on their crayfishery. Three years ago they began sampling the catches to look for any changes in average size. To date no changes have been detected. They also did some tagging to monitor crayfish movements. They have just completed analyzing that data, which indicates that crayfish did move from other areas into the areas which were being harvested. This data collection was undertaken primarily out of curiosity, not because they have concerns about the fishery (Smith pers. comm 1991).

It was Mr. Smith's recommendation to the Montana Department of Fish, Wildlife, and Parks that anglers be required to report the number of traps fished and the time they were fished in addition to the number of pounds harvested. This would give Montana an estimate of the catch per unit effort without using much staff time to monitor the fishery in the field. In 
addition, Mr. Smith recommended that anglers be required to be specific about the location of the catches, especially on large river systems. He also expressed some concern about crayfish picking up pollutants such as dioxin. He suggested that any questionable waters be tested for crayfish toxicity (Smith pers. comm. 1991).

\section{British Columbia}

In British Columbia there is both a recreational and a commercial crayfishery. Neither fishery has been given much attention by the British Columbia Ministry of Environment. The biologist I spoke with stated that they do not even know for certain how much of the province is occupied by crayfish (Sunde pers. comm. 1991).

Recreational anglers are allowed to trap crayfish if they are in possession of an angling license. There is no season or limits, however, they are requested to release berried females. The biologist I spoke with has no idea how many recreational crayfish anglers there are in British columbia (Sunde pers. comm. 1991).

The province of British Columbia issues approximately 20 to 30 commercial crayfish licenses every year at a cost of $\$ 5.00$ per license. A separate license is needed for every water body to be fished. There are no seasons or limits, and the license is valid from the date of issuance until December 31st. The minimum size is $9 \mathrm{~cm}$ measured from the rostrum to the tip of the tail. Berried females must be released. Traps must be designed to impound rather than entangle, i.e. no gill nets are allowed (Sunde pers. comm. 1991).

British Columbia does not provide licenses for every water body. Some waters, that are used heavily by recreational crayfish anglers, are closed to harvest. To date, the province has closed approximately 2 to 3 rivers and 3 to 4 lakes to commercial harvest (Sunde pers. comm. 1991).

Commercial fisherman are required to report information about their catch to the provincial government. About half of those who are issued licenses submit their reports. (It is assumed that the others did not fish or were unsuccessful). They are required to state the number of pounds harvested, the number of undersized crayfish released, the number of berried females released, the number of traps-nights fished, and the bait used. Generally, anglers harvest crayfish by the hundreds of pounds (as opposed to thousands of pounds). Mr. Sunde was unaware of any problems that have occurred due to over-fishing. He stated that the data that comes in on the angler's reports is so sparse they have made no attempt to do any type of analysis of the data. 
The commercial crayfish fishery began in California in 1970. From 1970 to 1975 the fishery was unrestricted and the mean length of crayfish caught declined from $104 \mathrm{~mm}$ to $90 \mathrm{~mm}$. In 1975 regulations were imposed including a minimum size of $92 \mathrm{~mm}$ total length with the catch sorted on the boat, and undersized crayfish returned to the water immediately. In addition, restrictions were put on the use and design of transport boxes in an attempt to increase transport survival. By 1976 the minimum size of the animals sent for processing was raised to $102 \mathrm{~mm}$. Following the establishment of these practices the yield and size was maintained until 1980, which suggested that the area was not being over-fished (Lowery and Holdich 1988). The fishery harvests 500,000 pounds per year.

There is a long set of complex regulations which govern the fishery (Appendix E), however the biologist I spoke with felt that they really do not have a good handle on the resource (Cordone pers. comm. 1991). The state did attempt to study the crayfish fishery in the Sacramento delta, but had only limited success due to the difficulty of working with crayfish and the difficulty of working in the delta.

Mr. Cordone stated that when the fishery first got started there were numerous social conflicts between anglers and crayfishers. However, the number of complaints has gradually declined until now there are hardly any problems.

The crayfishers periodically request that the fishery be made a limited entry fishery. The state has declined to do this because of the administrative problems of these types of fisheries. In addition the crayfishers also periodically request that the lakes and reservoirs be opened to commercial harvest. The state has consistently denied this request because of pressure from the black bass anglers who feel that this would be detrimental to their interests. Mr. Cordone did not feel there was any real biological reason why some of these lakes could not be opened on an experimental basis.

Utah

Utah has no commercial crayfish fishery. Recreational crayfishing is allowed and there are no regulations governing this activity (Shaddick pers. comm. 1991).

Crayfish distribution and composition in Utah are poorly documented. It appears that Utah has only one native crayfish species, and that only north of salt Lake county. However, in recent years crayfish have been introduced into numerous waters around the state. The state is concerned primarily with gathering more information about their crayfish populations and 
with controlling illegal introductions (Johnson 1986).

\section{wyoming}

Wyoming does not have a commercial crayfish fishery, nor do they have any regulations on recreational harvest. In Wyoming, crayfish are considered to be a valuable fish forage in most waters where they occur, but several potential problems with introduced crayfish are of concern to fisheries managers. These concerns include possible impacts to native species, possible forage imbalance in some trout fisheries, and the loss of aquatic macrophytes in aquatic systems where plants are ecologically important (Hubert 1988).

\section{Alberta}

Alberta has no commercial or recreational crayfishery. Crayfish are believed to be native to the Beaver River system in northeastern Alberta only. Alberta biologists are also aware of one illegal introduction of crayfish near Grand Prairie. All the crayfish in Alberta are small and do not attract any interest as a human food (Watson pers. comm. 1991).

\section{summary of western crayfish management}

A minimum size limit seems to be standard for all the states and provinces which have a commercial crayfish harvest. The biological basis for the minimum size limit is that it allows the crayfish the opportunity to spawn at least once before it is harvested. However, this limit also closely correlates to the minimum size that is acceptable for the market.

Some areas have seasons but California and British Columbia do not. Since crayfish are not vulnerable to trapping during the cold months, a season restriction is probably not necessary.

All the agencies I spoke with require the release of berried females. Since the Scandinavians will not accept berried females anyway, this is no great hardship on the anglers. The primary benefit of this regulation (as with the minimum size limit) is that the anglers are required to sort their catch at the time of harvest and release undersized and berried females alive.

It is also apparent that this fishery is not getting very much attention. Although none of the biologists I spoke with were aware of any biological problems that have occurred from commercial crayfish fishing, none of the states have really gathered any data which provide any solid evidence one way or the other. Most of the problems that have arisen have been between competing user groups or sometimes between competing commercial crayfishers. 
of the states I contacted, only oregon and California have a significant crayfish harvest. In the other states, the interest in crayfishing fluctuates with the market price, however it is not a major fishery at any time. 
COMMERCIAL CRAYFISH REGULATIONS IN THE WESTERN U.8. AND CANADA JUNE 1991

Commercial

License

State Require. Season Size
Collection Transport Special Method Restrict. Regula.

\begin{tabular}{|c|c|c|c|c|c|c|}
\hline MT & $\begin{array}{l}\text { Class B } \\
\text { commerci } \\
\text { al } \\
\text { license: } \\
\$ 200 / y r \\
+ \text { free } \\
\text { crayfish } \\
\text { permit } \\
\text { for a } \\
\text { specific } \\
\text { water + } \\
\$ 1,000 . \\
\text { surety } \\
\text { bond }\end{array}$ & $\begin{array}{l}\text { Year } \\
\text { round }\end{array}$ & $\begin{array}{l}35 / 8 " \\
\text { for } \\
\text { Pacifas } \\
\text { ticus } \\
\text { and } 3 " \\
\text { for } \\
\text { Orconec } \\
\text { tes }\end{array}$ & $\begin{array}{l}\text { crayfish } \\
\text { or minnow } \\
\text { traps not } \\
>3 \text { ' dia. } \\
\text { Crab } \\
\text { rings, by } \\
\text { hand, } \\
\text { hook and } \\
\text { line, or } \\
\text { experimen } \\
\text { tal gear } \\
\text { as } \\
\text { approved } \\
\text { by MDFWP }\end{array}$ & $\begin{array}{l}\text { May } \\
\text { transpo } \\
\text { rt only } \\
\text { between } \\
\text { the } \\
\text { areas } \\
\text { harvest } \\
\text { ed and } \\
\text { the } \\
\text { point } \\
\text { of } \\
\text { sale, } \\
\text { holding } \\
\text { or or } \\
\text { process } \\
\text { ing. }\end{array}$ & $\begin{array}{l}\text { Undersized } \\
\text { and berried } \\
\text { females } \\
\text { immediately } \\
\text { released. } \\
\text { Sorting } \\
\text { error 5\%. } \\
\text { Traps } \\
\text { disinfected } \\
\text { \& tended } \\
\text { every } 72 \\
\text { hrs. All } \\
\text { gear must } \\
\text { have gear } \\
\text { tags. Only } \\
\text { one permit } \\
\text { per water } \\
\text { body (with } \\
\text { exceptions) } \\
\text { No gear } \\
\text { within } 100 \\
\text { yds of any } \\
\text { public boat } \\
\text { ramp or } \\
\text { dock. } \\
\text { Monthly } \\
\text { reports } \\
\text { required. }\end{array}$ \\
\hline
\end{tabular}




\begin{tabular}{|c|c|c|c|c|c|c|}
\hline ID & $\begin{array}{l}\text { Commerci } \\
\text { al fish } \\
\text { license } \\
\$ 100 .+ \\
\text { gear tag } \\
\$ 1.00 / \text { po } \\
t\end{array}$ & $\begin{array}{l}4 / 1 \\
\text { to } \\
10 / 31\end{array}$ & $35 / 8 "$ & $\begin{array}{l}\text { Attended } \\
\text { seines or } \\
\text { crayfish } \\
\text { or minnow } \\
\text { traps not } \\
>3^{\prime} \text { dia. }\end{array}$ & $\begin{array}{l}\text { Trans- } \\
\text { port } \\
\text { from } \\
\text { capture } \\
\text { area to } \\
\text { point } \\
\text { of sale } \\
\text { or } \\
\text { holding } \\
\text { only }\end{array}$ & $\begin{array}{l}\text { Undersized } \\
\text { and berried } \\
\text { females } \\
\text { released } \\
\text { immediately } \\
\text { only } \\
\text { certain } \\
\text { waters } \\
\text { open. No } \\
\text { fishing } \\
\text { within } 100 \\
\text { yds of any } \\
\text { public boat } \\
\text { ramp or } \\
\text { dock. Must } \\
\text { have gear } \\
\text { tags. Traps } \\
\text { checked } \\
\text { every } 96 \\
\text { hrs. } \\
\text { Monthly } \\
\text { report. }\end{array}$ \\
\hline WA & $\begin{array}{l}\text { Shell- } \\
\text { fish pot } \\
\text { license } \\
\$ 50 .\end{array}$ & $\begin{array}{l}\text { lst } \\
\text { Mon } \\
\text { in } \\
\text { May } \\
\text { to } \\
\text { Oct } \\
31 . \\
\text { Some } \\
\text { excep } \\
\text { tions }\end{array}$ & $31 / 4 "$ & $\begin{array}{l}\text { Crayfish } \\
\text { pots or } \\
\text { rings } \\
\text { only }\end{array}$ & & $\begin{array}{l}400 \text { pot max } \\
\text { per person. } \\
\text { No fishing } \\
\text { within 1/4 } \\
\text { mi of } \\
\text { developed } \\
\text { parks. only } \\
\text { certain } \\
\text { waters } \\
\text { open, with } \\
\text { max number } \\
\text { of pots } \\
\text { allowed. } \\
\text { Must } \\
\text { maintain } \\
\text { harvest } \\
\text { log. } \\
\text { Immediate } \\
\text { release of } \\
\text { berried } \\
\text { females and } \\
\text { undersized } \\
\text { crayfish. }\end{array}$ \\
\hline
\end{tabular}




\begin{tabular}{|c|c|c|c|c|c|c|}
\hline OR & $\begin{array}{l}\text { Commer- } \\
\text { cial } \\
\text { fishing } \\
\text { licence } \\
\$ 40 .\end{array}$ & $\begin{array}{l}4 / 1 \\
\text { to } \\
10 / 31\end{array}$ & $35 / 8^{\prime \prime}$ & $\begin{array}{l}\text { Pots or } \\
\text { rings } \\
\text { only }\end{array}$ & $\begin{array}{l}\text { Need } \\
\text { trans- } \\
\text { port } \\
\text { permit }\end{array}$ & $\begin{array}{l}\text { Undersized } \\
\text { and berried } \\
\text { females } \\
\text { released. } \\
\text { Some waters } \\
\text { closed. All } \\
\text { gear must } \\
\text { be labeled } \\
\text { with } \\
\text { identifica- } \\
\text { tion } \\
\text { number. }\end{array}$ \\
\hline$B C$ & $\begin{array}{l}\text { Crayfish } \\
\text { license } \\
\$ 5.00\end{array}$ & $\begin{array}{l}\text { Year } \\
\text { round }\end{array}$ & $9 \mathrm{~cm}$ & $\begin{array}{l}\text { Gear } \\
\text { which } \\
\text { impounds } \\
\text { rather } \\
\text { than } \\
\text { entangles } \\
\text { is legal }\end{array}$ & $\begin{array}{l}\text { No } \\
\text { trans- } \\
\text { plantin } \\
\text { g from } \\
\text { water } \\
\text { body to } \\
\text { another }\end{array}$ & $\begin{array}{l}\text { Catch } \\
\text { record must } \\
\text { be turned } \\
\text { in when } \\
\text { license } \\
\text { expires. } \\
\text { Undersized, } \\
\text { berried } \\
\text { females, } \\
\text { and game } \\
\text { fish } \\
\text { released } \\
\text { unharmed }\end{array}$ \\
\hline
\end{tabular}




\begin{tabular}{|c|c|c|c|c|c|c|}
\hline $\mathrm{CA}$ & $\begin{array}{l}\text { Commerci } \\
\text { al fish } \\
\text { license } \\
(\$ 40 .)+ \\
\text { free } \\
\text { crayfish } \\
\text { permit. }\end{array}$ & $\begin{array}{l}\text { Year } \\
\text { round }\end{array}$ & $\begin{array}{l}35 / 8^{\prime \prime} \\
\text { on } \\
\frac{\text { Pacifas }}{\text { ticus }} \\
\text { only }\end{array}$ & $\begin{array}{l}\text { Hand, } \\
\text { hook \& } \\
\text { line, dip } \\
\text { net not } \\
>6 \text { or } \\
\text { trap not } \\
>3:\end{array}$ & $\begin{array}{l}\text { Contain } \\
\text { ers } \\
\text { vented } \\
\text { at } \\
\text { bottom, } \\
\text { depth } \\
\text { of } \\
\text { crayfis } \\
\text { h not > } \\
13^{\prime \prime}\end{array}$ & $\begin{array}{l}\text { Immediate } \\
\text { return of } \\
\text { undersized } \\
\text { and berried } \\
\text { females. } \\
\text { lof sorting } \\
\text { error } \\
\text { allowed. } \\
\text { Traps must } \\
\text { be tagged } \\
\text { with permit } \\
\text { number. } \\
\text { Trapping } \\
\text { area must } \\
\text { be } \\
\text { buoyed.Trap } \\
\text { s must be } \\
\text { checked } \\
\text { every } 72 \\
\text { hrs. All } \\
\text { lakes and } \\
\text { reservoirs } \\
\text { are closed. } \\
\text { only some } \\
\text { counties } \\
\text { are open. }\end{array}$ \\
\hline
\end{tabular}




\section{LITERATURE CITED}

Abrahamsson, S.A. 1966. Dynamics of an isolated population of the crayfish Astacus astacus Linne. Oikos 17: 96-107.

Abrahamsson, S.A. 1973. The crayfish Astacus astacus in Sweden and the introduction of the American crayfish Pacifasticus leniusculus. Freshwater Crayfish 1: 27-40.

Abrahamsson, S.A.A. and C.R. Goldman. 1970. Distribution density, and production of the crayfish Pacifasticus leniusculus Dana in Lake Tahoe, California-Nevada. Oikos 21:83-91.

Allen, K.R. 1939. A note on the food of pike in Windermere. J. of Anim. Ecol. 8: 72-75.

Barber, M.R., B.L. Renberg, J.J. Vella, A.T. Scholz, K.L. Woodward, and S. Graves. 1990. Assessment of the fishery improvement opportunities on the Pend Oreille River. 1989 Annual Report. Upper Columbia United Tribes Fisheries Center Department of Biology, Eastern Washington University. prepared for Bonneville Power Administration, Division of Fish and Wildlife.

Becker, D. 1991. Personnel communication. Confederated Salish and Kootenai Tribes, Pablo, Montana.

Benson, N.G. 1953. Seasonal fluctuations in the feeding of brook trout in the Pigeon River, Michigan. Trans. Am. Fish Soc. $83: 76-83$.

Berg, R. 1991. personnel communication. Montana Department of Fish, Wildlife, and Parks, Missoula, Montana.

Bonde, T. and J.E. Maloney. 1960. Food habits of the burbot. Trans. Am. Fish. Soc. 89: 374-376.

Burgess, S.A. and J.R. Bider. 1980. Effects of stream habitat improvements on invertebrates, trout populations, and mink activity. J. Wildl. Manage. 44: 871-880.

Collazo, J.A. 1985. Food habits of nesting great blue herons at Heyburn State Park, Idaho. Northwest Science. 59:144-146.

Collins, N.C., H.H. Harvey, A.J. Tierney, and D.W. Dunham. 1983. Influence of predatory fish density on trapability of crayfish in ontario lakes. Can. J. Fish. Aquatic Sci. $40: 1820-1828$.

Cordone, A.J. 1991. Personnel communication. California 
Department of Fish and Game, Sacramento, California.

Dean, J.L. 1969. Biology of the crayfish orconectes causyi and its use of the control of weeds in trout lakes. Tech. Papers, U.S. Bur. Sport Fish and Wildl. 24.

Dearborn, N. 1932. Foods of some predatory furbearing animals in Michigan. Univ. Michigan Bull. School For. Conserv. 1:1-52. cited in Kaufmann, J.H. 1982. Raccoons and allies. in Chapman, J.A. and G.A. Feldhamer, eds. Wild Mammals on North America. Biology, Management, and Economics. Johns Hopkins Univ. Press, $1147 \mathrm{p}$.

Dorney, R.S. 1954. Ecology of marsh raccoons. J.Wildl. Manage. 18: $217-225$.

Dubets, H. 1954. Feeding habits of largemouth bass as revealed by gastroscope. Prog. Fish-Cult. 16: 134-136.

Eipper, A.W. 1956. Differences in vulnerability of the prey of nesting kingfishers. J.Wild. Manage. 20: 177-183.

Emery, A.R. 1975. Stunted bass: a result of competing cisco and limited crayfish stocks. in Clepper, H. ed. Black Bass Biology and Management. National Symposium on the Biology and Management of the Centrarchid Basses. Sport Fishing Institute, Washington, D.C.

Erlinge, S. 1969. Food habits of the otter (Lutra lutra) and the mink (Mustela vison) in a trout water in southern Sweden. oikos 20:1-7.

Flint, R.W. 1975a. Growth in a population of the crayfish Pacifasticus leniusculus from a subalpine environment. J. Fish. Res. Bd. Can. 32: 2433-2440.

Flint, R.W. 1975b. The natural history, ecology, and production of the crayfish Pacifasticus leniusculus, in a subalpine lacustrine environment. Dissertation, Univer. of Calif, Davis. 157 p. cited in McGriff, D. 1983. Growth, maturity, and fecundity of the crayfish, Pacifasticus leniusculus, from the Sacramento-San Joaquin Delta. Calif. Fish and Game. 69: 227-242.

Flint, R.W. 1977. Seasonal activity, migration, and distribution of the crayfish, Pacifasticus leniusculus, in Lake Tahoe. Am. Midl. Nat. 97:280-292.

Flint, R.W. and C.R. Goldman. 1977. Crayfish growth in Lake Tahoe: effects of habitat variation. J. Fish. Res. Bd. Can. $34: 155-159$. 
Frantz, T.C. and A. J. Cordone. 1970. Food of lake trout in Lake Tahoe. Calif. Fish and Game. 56: 21-35.

Gerell, R. 1967. Food selection in relation to habitat in mink (Mustela vison) in Sweden. Oikos 18: 233-246.

Goldman, C.R. and J.C. Rundquist. 1977. A comparitive ecological study of the California crayfish, Pacifasticus leniusculus (Dana), from two subalpine lakes (Lake Tahoe and Lake Donner). Freshwater Crayfish 3:51-80.

Gowing, H. and W.T. Momot. 1979. Impact of brook trout

(Salvelinus fontinalis) predation on the crayfish orconectes virilis in three Michigan lakes. J. Fish. Res. Bd. Can. 36:1191-1196.

Greer, K.R. 1955. Yearly food habits of the river otter in the Thompson Lakes region, as indicated by scat analysis. The Am. Midl. Nat. 54: 299-313.

Hackney, P.A. 1973. Ecology of the burbot (Lota lota) with special reference to its role in the Lake Opeongo fish community. cited in Emery, A.R. 1975. Stunted bass: a result of competing cisco and limited crayfish stocks. in Clepper, H. ed. Black Bass Biology and Management. National Symposium on the Biology and Management of the Centrarchid Basses. Sport Fishing Institute, Washington, D.C.

Hamilton, W.J. Jr. 1961. Late fall, winter and early spring foods of 141 otters from New York. New York Fish Game J. 8: 106109 .

Hepworth, D.K. and D.J. Duffield. 1987. Interactions between an exotic crayfish and stocked rainbow trout in Newcastle Reservoir, Utah. N.Am.J. Fish. Manage. 7: 554-561.

Hogger, J.B. 1984. A study of aspects of the biology and distribution of freshwater crayfish in the Thames catchment. Ph.D. Thesis, CNAA, UK. cited in Hogger, J.B. 1988. Ecology, population biology, and behavior. in Holdich, D.M. and R.S. Lowery, eds. Freshwater Crayfish: Biology, Management, and Exploitation. Croom Helm, London. $498 \mathrm{p}$.

Hogger, J.B. 1988. Ecology, population biology, and behavior. in Holdich,D.M. and R.S. Lowery, eds. Freshwater Crayfish: Biology, Management, and Exploitation. Croom Helm, London. $498 \mathrm{p}$.

Hubert, W.A. 1988. Survey of Wyoming crayfishes. Great Basin Naturalist. $48: 370-372$. 
Huner,J.V. and J.E. Barr. 1984. (revised). Red swamp crawfish: biology and exploitation. Baton Rouge, Louisiana, USA, Louisiana Sea Grant College Program, Center for Wetland Resources, Louisiana State Univ. 136 p. cited in Hogger, J.B. 1988. Ecology, population biology, and behavior. in Holdich, D.M. and R.S. Lowery, eds. Freshwater Crayfish: Biology, Management, and Exploitation. Croom Helm, London. $498 \mathrm{p}$.

Jeppson, P.W. and W.S. Platts. 1959. Ecology and control of the Columbia squawfish in northern Idaho lakes. Trans. Am. Fish Soc. 88: 197-202.

Johnson, J.E. 1986 Inventory of Utah crayfish with notes on current distribution. Great Basin Naturalist. 46: 625-631.

Kaufmann, J.H. 1982. Raccoons and allies. in Chapman, J.A. and G.A. Feldhamer, eds. Wild Mammals on North America. Biology, Management, and Economics. Johns Hopkins Univ. Press, $1147 \mathrm{p}$.

Kimble, R.B. and A. Ensminger. 1959. Ducks food habits in southwestern Louisiana marshes following a hurricane. J. wild. Manage. 23: 453-455.

Knudsen, G.J. and J.B. Hale. 1968. Food habits of otters in the Great Lakes region. J. Wildl. Manage. 32: 89- 93.

Korschgen, L.J. 1957. Food habits of the coyote in Missouri. J. Wildl. Manage. 21:424-435.

Korschgen,L.J. 1958. December food habits of mink in Missouri. J. Mammal. 39:521-527.

Larson, A.M. 1989. Crayfish: Minnesota's new cash crop? The Fisherman. $71: 12-15$.

Lauhacinda, V. and E.P. Hill. 1977. Winter food habits of river otters from Alabama and Georgia. Proc. Annual Conf. S.E. Assoc. Fish and Wildlife Agencies. 31: 246- 253 .

Leathe, S.A. and P.J. Graham. 1982. Flathead Lake fish food habits study. Final Report. Montana Department of Fish, Wildlife, and Parks, and Environmental Protection Agency.

Leonard, J.W. and F.A. Leonard. 1946. An analysis of the food habits of rainbow trout and lake trout in Birch Lake, Cass county, Michigan. Trans. Am. Fish Soc. 76:301-314.

Liers, E.E. 1951. Notes on the river otter (Lutra canadensis). J. Mammal. 32: 1-9. 
Lewis, W.M., G.E. Gunning, E. Lyles, and W.L. Bridges. 1961. Food choice of largemouth bass as a function of availability and vulnerability of food items. Trans. Am. Fish Soc. $90: 277-280$.

Lewis, W.M., R. Heidinger, W. Kirk, W. Chapman, and D. Johnson. 1974. Food intake of the largemouth bass. Trans. Am. Fish. Soc. $103: 277-280$.

Linscombe, G., N. Kinler, and R.J. Aulerich. 1982. Mink. in Chapman, J.A. and G.A. Feldhamer, eds. Wild Mammals on North America. Biology, Management, and Economics. Johns Hopkins Univ. Press, $1147 \mathrm{p}$.

Lodge, D.M., A.L. Beckel, and J.J. Magnuson. 1985. Lake bottom tyrant. Natural History. 8: 33-36.

Lorman, J.G. and J.J. Magnuson. 1978. The role of crayfishes on aquatic ecosystems. Fisheries 3: 8-10.

Lowery, G.R. 1966. Production and food of cutthroat trout in three Oregon streams. J. Wildl. Manage. 30:754-766.

Lowery, R.S. and D.M. Holdich. 1988. Pacifasticus leniusculus in North America and Europe, with details of the distribution of introduced and native crayfish species in Europe. in Lowery, R.S. and D.M. Holdich, eds. Freshwater Crayfish: Biology, Management and Exploitation. Croom Helm, London. $498 \mathrm{p}$.

Maloney, J.E. and F.H. Johnson. 1955. Life histories and interrelationships of walleye and yellow perch, especially during their first summer, in two Minnesota lakes. Trans. Am. Fish. Soc. 85:191-202.

Mason, J.C. 1975. Crayfish production in a small woodland stream. Freshwater Crayfish. 2: 449-479.

McGriff,D. 1983. Growth, maturity, and fecundity of the crayfish, Pacifasticus leniusculus, from the Sacramento-San Joaquin Delta. Calif. Fish and Game. 69: 227-242.

Momot, W.T. 1965. Food habits of the brook trout in West Lost Lake. Trans. Am. Fish Soc. 94: 188-191.

Momot, W.T. 1967. Effects of brook trout predation on a crayfish population. Trans. Am. Fish. Soc. 96: 202-209.

Momot, W.T. 1985. Production and exploitation of the crayfish orconectes virilis in northern climates. in Jamieson, G.S. and N. Bourne, eds. North Pacific workshop on stock 
assessment and management of invertebrates. Can J. Fish. Aquat. Sci. (Special Publ.) 92:154-167.

Momot, W.T 1988. Orconectes in North America and elsewhere. in Holdich, D.M. and R.S. Lowery, eds. Freshwater Crayfish: Biology, Management, and Exploitation. Croom Helm, London. $498 \mathrm{p}$.

Momot, W.T. and G.H. Gowing. 1972. Differential seasonal migration of the crayfish orconectes virilis (Hagen) in marl lakes. Ecology 53: 479-483.

Momot, W.T. and H. Gowing. 1983. Some factors regulating cohort production of the crayfish, orconectes virilis. Freshwater Biology 13:1-12.

Momot, W.T, H. Gowing, and P.D. Jones. 1978. The dynamics of crayfish and their role in the ecosystem. Am. Midl. Nat. $99: 10-35$.

Mullan, J.W. and R.L. Applegate. 1970. Food habits of five centrarchids during filling of Beaver Reservoir 1965-1966. Bureau of Sport Fish and Wildlife Tech. Paper \#50. 16 p.

Nigro, A.A. 1990. Status and habitat requirements of white sturgeon populations in the Columbia River downstream from McNary Dam. Annual Progress Report. Oregon Department of Fish and Wildlife, Washington Department of Fisheries, U.S. Fish and Wildlife Service, National Marine Fisheries service. Funded by Bonneville Power Administration, Division of Fish and Wildlife.

Nigro, A.A., T.T. Terrell, L.G. Beckman, W.R. Persons, and W.R. Nelson. 1983. Assessment of the fisheries and limnology of Lake Roosevelt. Annual Report 1982. U.S. Fish and Wildlife Service, Seattle National Fishery Research Center, Grand Coulee Substation. Prepared for the U.S. Bureau of Reclamation.

Parson, J.W. 1955. The trout fishery of the tailwater below Dale Hollow Reservoir. Trans. Am. Fish. Soc. 85:75-92.

Pflug, D.E. and G.B. Pauley. 1984. Biology of smallmouth bass in Lake Sammamish, Washington. Northwest Science. 58: 118-130.

Rahel, F.J. and R.A. Stein. 1988. Complex predator-prey interactions and predator intimidation among crayfish, piscivorous fish, and small benthic fish. Oecologia 75: 9498.

Ricker, W.C. 1975. Computation and interpretation on biological statistics of fish populations. Bulletin 191. Department of 
the Environment, Fisheries and Marine Service, ottawa, Canada.

Rickett, J.D. 1974. Trophic relationships involving crayfish of the genus orconectes in experimental ponds. Prog. Fish-cult. $36: 207-211$.

Ryder, R.A. 1954. Further investigation of $f$ ish predation of otter in Michigan. M.S. Thesis. Univ. of Michigan. $15 \mathrm{p}$. cited in Lauhacinda, V. and E.P. Hill. 1977. Winter food habits of river otters from Alabama and Georgia. Proc. Annual Conf. S.E. Assoc. Fish and Wildlife Agencies. 31: $246-253$.

Ryder, R.A. 1955. Fish predation by otter in Michigan. J.Wildl. Manage, 19:497-498.

Saiki, M.K. and J.C. Tash. 1979. Use of cover and dispersal by crayfish to reduce predation by largemouth bass. American Fish Soc. Spec. Publ. 6, 44-48. cited in Hogger, J.B. 1988 . Ecology, population biology, and behavior. in Holdich, D.M. and R.S. Lowery, eds. Freshwater Crayfish: Biology, Management, and Exploitation. Croom Helm, London. 498 p.

Salyer, J.C. III, and K.F. Lagler. 1946. The eastern belted kingfisher (Megaceryle alcyon alcyon) in relation to fish management. Trans. Am. Fish. Soc. 76: 97-117.

Shaddick, F. 1991 Personnel communication. Utah Division of Wildlife Resources, Salt Lake City, Utah.

Sheldon, A.L. 1989. A reconnaissance of crayfish populations in western Montana. Prepared for the Montana Department of Fish, wildlife, and Parks.

Shimizu, S.J. and C.R. Goldman. 1983. Pacifasticus leniusculus (Dana) production in the Sacramento River. in Freshwater Crayfish V. C.R. Goldman, ed. AVI Publishing company, Inc. Westport, Connecticut. $569 \mathrm{p}$.

Smith, A. 1991. personnel communication. oregon $\mathrm{Fish}$ and Wildlife, Portland, Oregon.

Snow, H.E. 1971. Harvest and feeding habits of largemouth bass in Murphy Flowage, Wisconsin. Wis. Dept. Nat. Res. Tech. Bull. No. 50. 25 p. cited in Lewis, W.M., R. Heidinger, W. Kirk, W. Chapman, and D. Johnson. 1974. Food intake of the largemouth bass. Trans. Am. Fish. Soc. 103:277-280.

Statler, D.P. 1990. Dworshak Reservoir investigations - trout, bass, and forage species. Annual report 1989. Nez Perce Department of Fisheries Resource Management. Bonneville 
Power Administration, Division of Fish and Wildlife.

Sunde, L. 1991. personnel communication. British Columbia Ministry of the Environment, Victoria, British Columbia.

Svardson, G. 1949. Stunted crayfish populations in Sweden. Drottningholm Reports 29: 135-145.

Taub, S.H. 1972. Exploitation of crayfish by largemouth bass in a small ohio pond. Prog. Fish-Cult. 34: 55-58.

Toweill, D.E. and J.E. Tabor. 1982. River otter. in Chapman, J.A. and G.A. Feldhamer, eds. Wild Mammals on North America. Biology, Management, and Economics. Johns Hopkins Univ. Press, $1147 \mathrm{p}$.

Van Vooren, A. 1991. personnel communication. Idaho Department of Fish and Game, Boise, Idaho.

Waller, D.W. 1962. Feeding behavior of minks at some Iowa marshes. M.S. Thesis. Iowa State University. 90 p. cited in Linscombe, G., N. Kinler, and R.J. Aulerich. 1982. Mink. in Chapman, J.A. and G.A. Feldhamer, eds. Wild Mammals on North America. Biology, Management, and Economics. Johns Hopkins Univ. Press, $1147 \mathrm{p}$.

Watson, M. 1991. Personnel communication. Alberta Department of Forestry, Lands, and Wildlife, Edmonton, Alberta.

Weagle, K.V. and G.W. Ozburn. 1972. Observations on aspects of the life history of the crayfish orconectes virilis (Hagen) in northwestern ontario. Can. J. Zool. 50:366-370.

Westman, K. 1985. Effects of habitat modification on freshwater crayfish. in J.S. Alabaster, ed. Habitat Modification and Freshwater Fisheries. EIFAC Symposium, Butterworth, London.

Wood, B. 1991. personnel communication. Washington Department of Fisheries, Brinnon, Washington. 
